\title{
GLYCAEMIC INDEX OF SELECTED FOODSTUFFS IN HEALTHY PERSONS
}

\author{
Zuzana Fajkusova ${ }^{a *}$, Tereza Jadviscokova ${ }^{a}$, Maria Pallayova ${ }^{\mathrm{b}}$, Veronika Matuskova ${ }^{\mathrm{a}}$, \\ Jiri Luza ${ }^{a}$, Galina Kuzmina ${ }^{a}$
}

\author{
a Department of Physiology and $2^{\text {nd }}$ Department of Medicine, Faculty of Medicine and Dentistry, Palacky University, \\ Olomouc, Czech Republic \\ ${ }^{b}$ Department of Physiology and $1^{\text {st }}$ Department of Medicine, Faculty of Medicine, P. J. Safarik University, Kosice, Slovak \\ Republic \\ e-mail: zuzana.fajkusova@seznam.cz; nastasja.filipovna@centrum.cz
}

Received: September 30, 2007; Accepted: November 11, 2007

Key words: Nutrition/Glycaemic index/CGMS

\begin{abstract}
Aims: The aim of this study was to determine glycaemic index (GI) of 10 popular foodstuffs/mixed meals in healthy persons.

Methods: Ten tested foodstuffs and glucose standard were consumed in three replicates in the course of a defined 9-day meal plan: puffed rice squares with chocolate, dark chocolate, white bread, honey and glucose for breakfast (at 7 a.m.) and dinner (at 8 p.m.); pasta with meat, fried fish with mashed potatoes, and buttered apricot dumplings for lunch (at 12 a.m.); wafers, puffed spelt squares with chocolate, and tomato soup for snack (at 4 p.m.). Each portion contained $50 \mathrm{~g}$ of carbohydrates and was consumed within 30 minutes. Glucose concentrations were measured by means of the Continous Glucose Monitoring System (CGMS ${ }^{\mathrm{TM}}$, Medtronic Minimed, Northridge, CA, USA). The results were processed by Solutions Software (Medtronic Minimed, Northridge, CA, USA) and DegifXL4 software, Palacký University, Olomouc, CZ. Twenty healthy persons aged $21.9 \pm 1.39$ y (mean \pm SE), BMI $23.6 \pm 0.63 \mathrm{~kg} / \mathrm{m}^{2}$ completed the study.

Results: GI of tested foodstuffs ranged from $34.7 \%$ (chocolate) to $105.3 \%$ (puffed rice squares with chocolate). There were more than tenfold differences between minimal and maximal values of the GI for some foodstuffs. Significant interindividual differences were found between GIs of foodstuffs.

Conclusions: In twenty healthy persons the glycaemic indexes of ten popular foodstuffs were determined, to be added to the nutritional labels in order to facilitate the optimum meal planning.
\end{abstract}

\section{INTRODUCTION}

Glycaemic index (GI) is a measure of the hyperglycaemic power of food related to glucose. Since the pioneer papers of Otto ${ }^{1}$ and Jenkins ${ }^{2}$ it has become an important part of nutritional tabels ${ }^{3}$ in many countries. However, the GI may be influenced by various factors, so that the determined values cannot be automatically transferred from one centre to another.

At The Faculty of Medicine of Palacký University, Olomouc attempts to determine the GI started in 2004, originally using the traditional methods ${ }^{4-6}$ and recently also a new method based on CGMS and Software Solutions $^{7-12}$ and DegifXL ${ }^{13,14}$. Until now, the GI of only 6 foodstuffs had been determined. The aim of the present study was to determine the GI for other 10 popular foodstuffs/mixed meals.

\section{MATERIALS AND METHODS}

The study was performed in January and February 2007 as a part of the project DEGIF (IGA NR 7825-3).

\section{Subjects}

Twenty-five healthy persons gave their informed consent according to the Declaration of Helsinki approved by the local Ethics Committee and entered the study. There were five dropouts due to intercurrent illness. Twenty persons aged $21.9 \pm 1.39$ y (mean \pm SE), BMI $23.6 \pm$ $0.63 \mathrm{~kg} / \mathrm{m}^{2}$, completed the study.

\section{Tested foodstuffs}

Ten different foodstuffs/mixed meals with a known content of nutrients (Table 1) were tested. The tested meals were chosen from five different compartments of food: sweets, bakery, rice and spelt products and mixed meals. The choice of foods was also influenced by the amount of carbohydrates in one labeled marketed food package which should yield servings with $50 \mathrm{~g} \pm 5 \%$ of carbohydrates each. The portions were professionally prepared in the expected quality and quantity.

The foodstuffs were divided into 3 groups according to the time of consumption:

1. Foodstuffs for breakfast and dinner, consumed at 7 a. m. and 8 p.m.

2. Foodstuffs for lunch, consumed at 12 a.m.

3. Foodstuffs for snack, consumed at 4 p.m. 
Table 1. Content of nutrients and energy in one portion of tested foodstuff

\begin{tabular}{|c|c|c|c|c|}
\hline & \multicolumn{4}{|c|}{ Content of nutrients and energy } \\
\hline & $\begin{array}{l}\mathrm{CHO} \\
{[\mathrm{g}]}\end{array}$ & $\begin{array}{l}\text { Lipids } \\
\text { [g] }\end{array}$ & $\begin{array}{l}\text { Proteins } \\
\qquad[\mathrm{g}]\end{array}$ & $\begin{array}{c}\text { Energy } \\
{[\mathrm{kJ}]}\end{array}$ \\
\hline \multicolumn{5}{|l|}{ Meals for breakfast and dinner } \\
\hline $\begin{array}{l}\text { Puffed rice squares Racio } \\
\text { with dark chocolate }\end{array}$ & 50 & 19 & 7 & 1649 \\
\hline Dark chocolate & 50 & 62 & 13 & 3403 \\
\hline White bread Penam & 50 & 3 & 8 & 1133 \\
\hline Lime-blossom honey & 50 & 0 & 0 & 808 \\
\hline Glucose solution & 50 & 0 & 0 & 850 \\
\hline \multicolumn{5}{|l|}{ Meals for lunch } \\
\hline $\begin{array}{l}\text { Tin of Ravioli pasta with meat Heinz, } \\
\text { Eidam cheese Promil from Krkonoše }\end{array}$ & 50 & 32 & 36 & 1615 \\
\hline $\begin{array}{l}\text { Fried fish Delvita, Mashed potatoes } \\
\text { in powder Natura, Fresh butter Madeta }\end{array}$ & 50 & 34 & 16 & 2395 \\
\hline $\begin{array}{l}\text { Apricot dumplings Delvita, Fresh butter } \\
\text { Madeta }\end{array}$ & 50 & 27 & 55 & 2168 \\
\hline \multicolumn{5}{|l|}{ Meals for snack } \\
\hline Kolonáda Wafers Opavia & 50 & 31 & 4 & 2091 \\
\hline Puffed spelt squares Racio with chocolate & 50 & 22 & 9 & 1754 \\
\hline Tomato soup Vitana & 50 & 3 & 6 & 1077 \\
\hline
\end{tabular}

CHO-carbohydrates

Table 2. Defined meal plan: a total of 32 servings of ten foodstuffs and standard (glucose)

\begin{tabular}{|c|c|c|c|c|}
\hline Day & Breakfast 7 a.m. & Lunch 12 a.m. & Snack 4 p.m. & Dinner 8 p.m. \\
\hline 1 & - & $\begin{array}{l}1 \text { - Ravioli pasta, } \\
\text { cheese }\end{array}$ & 2 - Puffed spelt squares & 3 - Dark chocolate \\
\hline 2 & $4-$ Glucose & $\begin{aligned} 5 \text { - } & \text { Mashed potatoes, } \\
& \text { fried fish, butter }\end{aligned}$ & 6 - Wafers "Kolonáda" & 7 - Puffed rice squares \\
\hline 3 & 8 - White bread & $\begin{array}{l}9 \text { - } \begin{array}{l}\text { Buttered apricot } \\
\text { dumplings }\end{array} \\
\end{array}$ & 10 - Tomato soup & $\begin{array}{l}11 \text { - Lime-blossom } \\
\text { honey }\end{array}$ \\
\hline 4 & 12 - Dark chocolate & $\begin{array}{l}13 \text { - Ravioli pasta, } \\
\text { cheese }\end{array}$ & 14 - Puffed spelt squares & 15 - Glucose \\
\hline 5 & 16 - Puffed rice squares & $\begin{array}{c}17 \text { - } \begin{array}{c}\text { Mashed potatoes, } \\
\text { fried fish, butter }\end{array} \\
\end{array}$ & 18 - Wafers “Kolonáda” & 19 - White bread \\
\hline 6 & $\begin{array}{l}20 \text { - Lime-blossom } \\
\text { honey }\end{array}$ & $\begin{array}{l}21 \text { - Buttered apricot } \\
\text { dumplings }\end{array}$ & 22 - Tomato soup & 23 - Dark chocolate \\
\hline 7 & $24-$ Glucose & $\begin{array}{l}25 \text { - Ravioli pasta, } \\
\text { cheese }\end{array}$ & 26 - Puffed spelt squares & 27 - Puffed rice squares \\
\hline 8 & 28 - White bread & $\begin{array}{c}29 \text { - Mashed potatoes, } \\
\text { fried fish, butter }\end{array}$ & 30 - Wafers „Kolonáda“ & $\begin{array}{l}31 \text { - Lime-blossom } \\
\text { honey }\end{array}$ \\
\hline 9 & reserve & $\begin{array}{l}32 \text { - Buttered apricot } \\
\text { dumplings }\end{array}$ & - & - \\
\hline
\end{tabular}

Taking into consideration the content of nutrients and energetic values in each meal a defined meal plan was created (Tab. 2).

Each foodstuff was consumed in three replicates, except for soup, which was consumed two times only.
Energetic values of tested foodstuffs for the whole day were 6000-9000 kJ (Tab. 3).

\section{Study design}

1. CGMS sensor ${ }^{15-17}$, which was inserted subcutaneously into gluteal or lumbar region. 
2. Each volunteer received personal glucometer Advance (Hypoguard, Woodbridge, UK) and 50 Microdraw strips for calibration of the CGMS.

3. Volunteers were trained in handling the $\mathrm{CGMS}^{18}$. The average of two plasma glucose measurements on a glucometer Advance was taken to calibrate the CGMS every 12 hours.

4. In the course of 9 test days, each volunteer entered the exact times of eating, exercise, glucose concentration measured on a glucometer and data on the function of the CGMS into the protocol.

5. Every person received 32 servings of tested foods and the 9-day defined meal plan (Table 2).
6. Every volunteer was encouraged to drink $400 \mathrm{ml}$ of water or unsweetend tea together with each meal. No drinks were to be taken one hour before the meal start and two hours afterwards. Each meal was to be consumed within 30 minutes ${ }^{19}$.

7. Any differences in the daily routine were noted in the protocol.

8. Having accomplished the meal plan, data were downloaded from the CGMS monitors into the PC to calculate the GIs using the Software Degif XL4 (Ref. ${ }^{20}$ ), revised, manually corrected and completed according to protocols. The area under the curve has always been calculated for the period of time between 0 and $120 \mathrm{~min}$.

Table 3. Total daily content of nutrients and energy in meals in the course of 9 test days.

\begin{tabular}{|c|c|c|c|c|}
\hline Day & $\begin{array}{c}\text { CHO } \\
{[\mathbf{g}]}\end{array}$ & $\begin{array}{c}\text { Lipids } \\
{[\mathbf{g}]}\end{array}$ & $\begin{array}{c}\text { Proteins } \\
{[\mathbf{g}]}\end{array}$ & $\begin{array}{c}\text { Energy } \\
{[\mathbf{k J}]}\end{array}$ \\
\hline 1 & 150 & 116 & 59 & $8060+$ \\
\hline 2 & 201 & 83 & 28 & 7150 \\
\hline 3 & 202 & 33 & 68 & 5910 \\
\hline 4 & 200 & 116 & 59 & 8920 \\
\hline 5 & 203 & 87 & 36 & 7460 \\
\hline 6 & 200 & 91 & 74 & 8230 \\
\hline 7 & 198 & 73 & 52 & 7110 \\
\hline 8 & 205 & 68 & 29 & 6630 \\
\hline 9 & 48 & 27 & 55 & $2790++$ \\
\hline
\end{tabular}

+ except breakfast (only 3 test meals planned for the day 1 )

++ except breakfast, snack and dinner (only 1 test meal planned in the day 9)

CHO-carbohydrates

Table 4. GIs of selected foodstuffs. GI group: low (L), medium (M), high (H).

\begin{tabular}{|c|l|c|c|c|c|c|c|}
\hline No. & \multicolumn{1}{|c|}{ Foodstuff } & $\begin{array}{c}\text { Number } \\
\text { of tests }\end{array}$ & $\begin{array}{c}\text { GI } \\
(\%)\end{array}$ & $\begin{array}{c}\text { GI }_{\text {max }} \\
(\%)\end{array}$ & $\begin{array}{c}\text { GI }_{\text {mean }} \\
(\%)\end{array}$ & SE & $\begin{array}{c}\text { GI } \\
\text { group }\end{array}$ \\
\hline $\mathbf{1}$ & Glucose & 50 & 100.0 & 100.0 & 100.0 & 0.0 & H \\
\hline $\mathbf{2}$ & Dark chocolate (CHOC) & 34 & 1.0 & 79.0 & $* 34.7$ & 5.8 & L \\
\hline $\mathbf{3}$ & Puffed rice squares (RICE) & 45 & 32.0 & 328.0 & 105.3 & 17.6 & H \\
\hline $\mathbf{4}$ & White bread (BREAD) & 50 & 26.3 & 144.7 & 93.3 & 7.4 & H \\
\hline $\mathbf{5}$ & Lime-blossom honey (HONEY) & 48 & 24.3 & 169.3 & 76.7 & 8.4 & H \\
\hline $\mathbf{6}$ & Ravioli pasta, cheese (RAV) & 48 & 0.0 & 110.9 & $* 43.3$ & 6.8 & L \\
\hline $\mathbf{7}$ & Mashed potatoes, fried fish, butter (POT) & 52 & 19.9 & 236.6 & 94.0 & 13.7 & H \\
\hline $\mathbf{8}$ & Apricot dumplings, butter (DUMP) & 41 & 26.4 & 221.1 & 75.0 & 12.8 & H \\
\hline $\mathbf{9}$ & Puffed spelt squares (SPAL) & 41 & 22.8 & 141.4 & $* 63.7$ & 8.1 & M \\
\hline $\mathbf{1 0}$ & Wafers “Kolonáda” (CAKE) & 44 & 23.2 & 256.5 & 77.8 & 13.2 & H \\
\hline $\mathbf{1 1}$ & Tomato soup (SOUP) & 28 & 0.0 & 211.3 & $* 38.5$ & 12.1 & L \\
\hline
\end{tabular}

${ }^{*} \mathrm{p}<0.05$ in comparison to glucose 


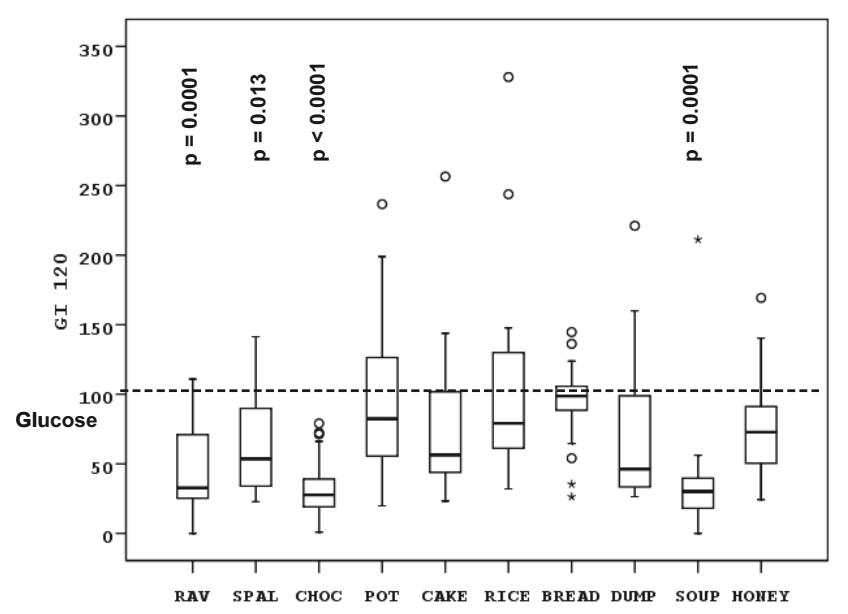

Fig. 1. Boxgraph: Variation of GIs of tested foodstuffs in comparison to glucose (medians and quartiles, - outliers, *extreme values). For abbreviations of foods see Table 4.

\section{Statistical analysis}

MS Excel and the statistical program SPSS v. 14.0 (SPSS Inc., Chicago, IL, USA) were used to analyze the data: An ANOVA was applied to compare the GIs of tested foods; $p<0.05$ was considered statistically significant.

\section{RESULTS}

In comparison to glucose $(\mathrm{GI}=100 \%)$, four tested foodstuffs (dark chocolate, Ravioli pasta with cheese, puffed spelt squares, tomato soup) were found to have lower GI $(p<0.05)$. No significant difference in glucose was found for the 6 other foodstuffs (puffed rice squares, white bread, lime-blossom honey, mashed potatoes with fried fish and butter, apricot dumplings with butter, wafers "Kolonáda").

Taking into consideration the traditional GI derived cathegories of foods, our results allow us to divide the tested foodstuffs/mix meals as follows:

1. group L: foods with low GI (GI $\leq 55 \%)$ : dark chocolate, Ravioli pasta with cheese, tomato soup

2. group M: foods with medium GI $(\mathrm{GI}=56-69 \%)$ : puffed spelt squares

3. group $\mathrm{H}$ : foods with high $\mathrm{GI}(\mathrm{GI} \geq 70 \%)$ : puffed rice squares, white bread, honey, mashed potatoes with fish fingers and butter, buttered apricot dumplings, wafers "Kolonáda".

See Table 4 and Figure 1 for details.

\section{DISCUSSION}

The glycaemic index is an important component of nutritional labels. International tables containing the GIs of about 750 different foodstuffs have been published ${ }^{3}$. The GIs of selected tested foodstuffs correspond to values of GI reported before. It is known that the GI of foods has a large inter- and intraindividual variability due to various factors. In this study we found more than tenfold difference between minimal and maximal values of the GI for some foodstuffs. Nevertheless, this finding corresponds with the findings of other authors ${ }^{21}$.

We applied the CGMS to investigate the GIs. The values of GI obtained by this method were not statistically different from values obtained by conventional method ${ }^{22}$. The CGMS sensor was safe for measuring the plasma glucose in the course of 9 days $^{23}$. The function and accuracy of glucose sensors inserted for more than 3 days was also demonstrated ${ }^{24}$. In our study a total of 640 tests with 11 meals were performed and 491 (77\%) of these were complete and suitable for further evaluation ${ }^{20}$.

Conventional methods for GI determination involve usually ten healthy persons and tests are performed in the morning hours following overnight fast. In our study 20 healthy persons were tested to increase the precision of the outcomes. In order to increase the capacity of the investigational period not only breakfasts but also lunches, snacks and dinners were used. However, the real benefits of this study design remain to be established. Additionally, it is important to evaluate the glycaemic profiles of individuals in response to a given food e.g. the glycaemic response to a mixed meal ${ }^{25}$ or to a complex food such as pizza.

\section{CONCLUSIONS}

In conclusion it may be said that the determined GIs of ten popular foods can facilitate nutritional labels to enable optimum meal planning ${ }^{26,27}$. A low GI was found for three foodstuffs (dark chocolate, Ravioli pasta with cheese, tomato soup), medium in puffed spelt squares and high GI in six foodstuffs (puffed rice squares, white bread, honey, mashed potatoes with fish fingers and butter, buttered apricot dumplings, wafers "Kolonáda"). Further studies focused on other foodstuffs and mixed meals are necessary.

\section{ACKNOWLEDGEMENTS}

The study was supported by the Research Project of the Ministry of Health, Czech Republic, IGA NR 7825-3.

Parts of this study were presented at the XL. Conference of Student Scientific Activities, Faculty of Medicine, Palacký University, Olomouc, 28.-29. 5. 2007 and at the XXVI. Conference of Young Physicians, Faculty of Medicine, Olomouc, 31. 5.-1. 6. 2007. 


\section{REFERENCES}

1. Otto H, Bleyer G, Pennartz M, Sabin G, Schauberger G, Spaethe R. Kohlenhydrataustausch nach biologischen Äquivalenten. In: Otto $\mathrm{H}$, Spaethe R, editors. Diätetik bei Diabetes mellitus [German: Exchange of Carbohydrates according to biological equivalents. In: Otto H, Spaethe R (Ed). Diet in diabetes mellitus]. Bern Stuttgart Wien: Verlag Hans Huber; 1973. p. 41-50.

2. Jenkins DJA, Wolever TMS, Taylor RH, Barker H, Fielden H, Baldwin JM, Bowling AC, Newman HC, Jenkins AL, Goff DV. Glycemic index of foods: a physiological basis for carbohydrate exchange. Amer J Clin Nutr 1981; 34:362-366.

3. Foster-Powell K, Holt SH, Brand-Miller JC. International table of glycaemic index and glycaemic load values. American Journal of Clinical Nutrition 2002 76:5-56.

4. Chlup R, Bartek J, Řezníčková M, Zapletalová J, Doubravová B, Chlupová L, et al. Determination of glycaemic index of selected foods (white bread and cereal bars) in healthy persons. Biomed Papers 2004; 148:17-25

5. Chlup R, Jelenová D, Kudlová P, Bartek J, Nakládalová M, Sečkař P, Zapletalová J Langová K, Pukowietz L, Chlupová K Konventionelle Bestimmung des glykämischen Indexes verschiedener Nahrungsmittel (Schokolade, Apfelmuss, Reisbrot, Yoghurt) bei pumpenbehandelten Typ-1 Diabetikern. Diabetologie und Stoffwechsel 2006; 1 (Suppl 1):154 (Abstract).

6. Chlup R, Payne M, Zapletalová J, Komenda S, Doubravová B, Řezničková M, Chlupová L, Sečkař P. Results of selfmonitoring on glucometer systems Advance and Optium in daily routine. Biomed Papers 2005; 149:127-139.

7. Mlčák P, Fialová J, Trnková K, Chlup R. A continous glucose monitoring system (CGMS) - A promising approach for improving metabolic control in person with type 1 diabetes mellitus treated by insulin pumps. Biomed. Papers 2004; 148:33-38.

8. Mlčák P, Chlup R, Boudová E, Bartek J, Zapletalová J. Vývoj koncentrace glukosy v intersticiální tekutině u nediabetiků s ohledem na detekci fenoménu svítání - pilotní studie (Assessment of Glucose Concentrations in Interstitial Fluid in Non-diabetic Subjects with Regard to detection of the Dawn Phenomenon - Pilot Study). Klin. Biochem. Metab. 2003; 10:44-49.

9. Chlupová K, Kohnert KD, Heinke P, Augstein P, Chlup R, Salzsieder E. Resultate kontinuierlicher Glukosemessungen (CGMS) unter ambulanten Bedingungen zur Beurteilung der Stoffwechseleinstellung bei T2DM. Diabetologie und Stoffwechsel 2006; 1(Suppl 1):94(Abstract).

10. Chlup R, Zapletalová J, Jelenová D, Chlupová K, Bartek J, Řehořová J Glykemický index hořké čokolády, ovocného jogurtu, jablečné přesnídávky a rýžovvých chlebíčků u zdravých osob. Diabetes a obezita 2006; 6(11):103-112.

11. Chlup R, Kudlová P, Sečkař P, Zapletalová J, Bartek J, Chlupová $\mathrm{K}$, Luža J. Glycaemic index of foods in healthy persons vs persons with type 1 diabetes mellitus. Diabetes 2006; 55(Suppl 1): A593(Abstract).

12. Peterson K, Chlup R, Kudlová P, Slezáková L, Zapletalová J, Langová K, Doubravová B, Bartek J, Sečkař P, Nakládalová M. Influence of Oral Antidiabetic Drugs on Hyperglycemic Power of Foods In Persons with Type 2 Diabetes Mellitus (DEGIF4). Diabetes 2007; 56(Suppl)1:A688(Abstract).

13. Chlup R, Sečkař P, Zapletalová J, Langová K, Kudlová P, Peterson K, Bartek J, Hučíková J. DegifXL - a new software program for de- termination of group-related and person-related glycemic indexes of foods by means of continuous glucose monitoring system CGMS. Acta Diab. Romana 2007; 33/1:351 (Abstract).

14. Chlup R, Sečkař P, Zapletalová J, Langová K, Kudlová $\mathrm{P}$, Chlupová $\mathrm{K}$, Bartek J, Jelenová D. Automated computation of glycaemic index for foodstuffs using continuous glucose monitoring. J Diabetes Sci Technol 2008; 2(1):in press.

15. Gross TM, Mastrotorato JJ. Efficacy and reliability of the continuous glucose monitoring system. Diabetes Technol Ther [serial on the internet]. 2000 [cited 2007 Sep 6];2 Suppl 1:S19-26.

16. Gross TM, Bode BW, Einhorn D, KayneDM, Reed JH, White NH, Mastrotorato JJ. Performance evaluation of the MiniMed continuous glucose monitoring system during patient home use. Diabetes Technol Ther 2000; 2(1):49-56.

17. Mastrotorato JJ. The MiniMed continuous glucose monitoring system. Diabetes Technol Ther 2000; 2(Suppl 1):13-8.

18. Medtronic MiniMed: CGMS System Gold MMT-7102W User guide. Northridge, CA. Medtronic MiniMed 2004.

19. Kudlová P, Stanislavová A. Edukace zdravých probandů v souvislosti s určováním glykemického indexu potravin (Czech: Education of healthy volunteers for the determination of glycemic index of foods). $1^{\text {st }}$ ed. In: Čáp J, Žiaková K, Nemčeková M, Holmanová E, editors. Teoria, výskum a vzdelávanie $\mathrm{v}$ ošetrovatelstve (Theory, research and education in nursing). Univerzita Komenského Bratislava, Jeseniova Lekárska Fakulta Martin, Ústav ošetrovatelstva, SR, Lékařská fakulta Univerzity Palackého Olomouc, Ústav teorie a praxe ošetřovatelství, ČR, Občianské združenie pre rozvoj zdravotníckeho vzdelávania v Martine. 2005:363-372.

20. Přibylová H, Pallayová M, Hučíková J, Luža J. Efficiency of new software programme DegifXL4 in determination of glycaemic indexes for foodstuffs. Biomed Pap Med Fac Univ Palacky Olomouc Czech Repub. submitted.

21. Rasmussen O. Day-to-day variation of the glycemic response in subjects with insulin-dependent diabetes with standardized premeal blood glucose and prandial insulin concentrations. Am J Clin Nutr. 1993; 57(6):908-11.

22. Chlup R, Jelenová D, Kudlová P, Chlupová K, Bartek J, Zapletalová J, Langová K, Chlupová L. Continuous glucose monitoring - a novel approach to the determination of the glycaemic index of foods (DEGIF 1). Exp Clin Endocrinol Diabetes 2006; 114:68-74.

23. Jadviščoková T, Fajkusová Z, Pallayová M, Luža J, Kuzmina G. Occurence of adverse events due to continous glucose monitoring. Biomed Pap Med Fac Univ Palacky Olomouc Czech Repub. 2007; 151:

24. Chlup R, Jelenová D, Chlupová K, Zapletalová J, Chlupová L, Bartek J. Function and Accuracy of Glucose Sensors beyond their stated Expiry Date. Diabetes Technology \& Therapeutics. 2005; 8(4):495-504.

25. Chew I, Brand JC, Thorburn AW, Truswell AS. Application of glycemic index to mixed meals. Am J Clin Nutr. 1988; 47(1):53-6.

26. Frost GS, Brynes AE, Bovill-Taylor C, Dornhorst A. A prospective randomised trial to determine the efficiency of a low glycaemic index diet given in addition to healthy eating and weight loss advice in patients with coronary heart disease. Eur J Clin Nutr. 2004; 58:121-127.

27. Ball SD, Keller KR, Moyer-Mileur LJ, Ding YW, Donaldson D, Jackson WD. Prolongation of satiety after low versus moderately high glycemic index meals in obese adolescents. Pediatrics. 2003; 111:488-494. 